\title{
Analisis Tingkat Kematangan Pelayanan Pada PT Telkom Sampit dengan Menggunakan Domain COBIT 5 DSS02 dan DSS03
}

\author{
Yusril Yusuf, Edo Tio Gunawan, Rakhma Sarita \\ Fakultas Ilmu Komputer, Sistem Informasi, Universitas Darwan Ali, Sampit, Indonesia \\ Email: 1yusrilyf01@gmail.com, ${ }^{2}$ edotiogunawan2@gmail.com, ${ }^{3}$ rakhmasarita155@gmail.com
}

\begin{abstract}
Abstrak-PT Telkom Sampit merupakan salah satu bagian dari PT Telekomunikasi Indonesia (Persero) Tbk (Telkom) yang berkontibusi dalam memenuhi kebutuhan komunikasi dan informasi untuk masyarakat. PT Telkom Sampit menyediakan beberapa produk layanan yaitu Wifi.id, IndiHome dan UseeTV. Dengan demikian, maka Telkom Sampit harus memberikan layanan yang baik dalam mengelola pelayanan. Adapun beberapa kendala yang sering terjadi diantaranya jaringan bermasalah, lemot dan rusak. Dari permasalahan tersebut, perlu dilakukan pengukuran tingkat kematangan pelayanan pada PT Telkom Sampit dengan menggunakan framework COBIT 5 fokus domain DSS02 (Mengelola Permintaan Layanan) dan DSS03 (Mengelola Masalah). Berdasarkan hasil penelitian yang sudah dilakukan PT Telkom Sampit berada pada level 4 yaitu Predictable Process (Proses Diukur), dimana sudah termasuk dalam level yang bagus untuk sebuah perusahaan, walaupun tidak sesuai dengan perkiraan yang harusnya berada pada level 5 yaitu Optimising Process (Proses Optimasi). Dengan penelitian ini, diharapkan dapat dijadikan evaluasi dalam meningkatkan kualitas kinerja pelayanan pada PT. Telkom Sampit dalam melayani customer.
\end{abstract}

Kata Kunci: COBIT 5; DSS; PT Telkom

Abstract-PT Telkom Sampit is one part of PT Telekomunikasi Indonesia (Persero) Tbk (Telkom) which contributes in meeting the communication and information needs of the community. PT Telkom Sampit provides several product services, namely Wifi.id, IndiHome and UseeTV. Thus, Telkom Sampit must provide good services in managing services. As for some of the obstacles that often occur including problems, slow and damaged. From these problems, it is necessary to measure the level of service improvement at PT Telkom Sampit using the COBIT 5 framework focusing on the domains DSS02 (Managing Service Requests) and DSS03 (Managing Problems). Based on research that has been done PT Telkom Sampit is at level 4, namely Predictable Process, which is included in a good level for a company, although it is not in accordance with estimates that should be at level 5, namely Optimizing Process (Optimization Process). With this research, it is hoped that it can be used as an evaluation in improving the quality of service performance at PT. Telkom Sampit in serving customers.

Keywords: COBIT 5; DSS; PT Telkom

\section{PENDAHULUAN}

Saat ini seluruh perusahaan terus bersaing dalam memberikan pelayanan terbaik, dan menggunakan teknologi informasi untuk menunjang bisnis mereka. Namun, ada beberapa perusahaan yang tidak menganalisis dan mengukur tingkat kinerja dari perusahaan mereka. Untuk meningkatkan kualitas kinerja pada suatu perusahaan diperlukan peningkatan, dengan memberikan pelayanan yang baik kepada pelanggan khususnya perusahaan jasa yang mempunyai produk layanan[1].

PT Telkom Sampit adalah bagian dari PT Telekomunikasi Indonesia (Persero) Tbk dan merupakan Badan Usaha Milik Negara (BUMN) yang telah berkontribusi untuk masyarakat Indonesia khususnya di bidang telekomunikasi. PT Telkom Sampit memiliki produk layanan yang ditawarkan kepada pelanggan diantaranya Wifi.id, IndiHome, dan UseeTV[2]. Pelayanan yang diberikan oleh PT Telkom Sampit sudah baik, namun masih ditemukan kendala dalam mengatasi insiden seperti jaringan bermasalah, lemot, dan rusak. Dari masalah tersebut, perlu dilakukan analisis tingkat kematangan pada pelayanan yang bertujuan untuk mengetahui tahapan atau level yang telah dicapai oleh PT Telkom Sampit dinyatakan dalam bilangan bulat.

Berdasarkan permasalah diatas, dalam mencapai tujuan tersebut perlu dilakukan analisis untuk mengukur dan mengetahui tingkat atau level pelayanan pada PT Telkom Sampit dengan menggunakan COBIT 5 framework. COBIT merupakan kerangka kerja yang menyediakan standar dalam kerangka kerja domain yang terdiri dari sekumpulan proses teknologi Informasi yang merepresentasikan aktivitas yang dapat dikendalikan dan terstruktur[3]. Domain yang digunakan pada COBIT 5 dalam melakukan audit tingkat layanan di PT Telkom Sampit adalah domain DSS (Delivery, Service, and Support) fokus ke sub domain DSS02 (Mengelola Permintaan Layanan) dan DSS03 (Mengelola Masalah).

Penelitian terkait dengan metode DSS adalah dalam menentukan tingkat pelayanan adalah Analisa Tingkat Kematangan Teknologi Informasi Pada Dinas Komunikasi Dan Informatika Kota Manado Menggunakan Framework COBIT 5 Domain Evaluate, Deirect, Monitor (EDM) dan Deliver, Service, and Support (DSS). Penelitian ini menggunakan framework COBIT 5 domain EDM dan DSS untuk mengukur tingkat kematangan teknologi informasi. Penulis mebuat kuesioner yang sudah disesuiakan dengan domain yang dipilih Kemudian jawaban hasil kusioner dihitung menggunakan rumus indeks, dari perhitungan tersebut diperoleh level tingkat kematangan TI nya[4]. Penelitian selanjutnya yang terkait dengan metode DSS yaitu Penerapan Metode COBIT 5.0 Domain DSS02 Dan DSS03 Untuk Mengukur Tingkat Kapabilitas Tata Kelola Sistem Di Pt. Indofood Cbp Sukses Makmur Tbk membantu dalam mengukur tingkat kapabilitas tata Kelola sistem dengan metode DSS fokus domain DSS02 dan DSS03. Dengan menggunakan metode kuesioner Skala Guttman, 2009 dengan menggunakan rumus konversi, lalu diperoleh hasil level kapabilitas tata kelola sistem pada PT. Indofood[3]. Analisis Pengukuran Kualitas Pelayanan Sistem Informasi Perbankan Dengan Menggunakan COBIT 5, mengimplementasikan domain DSS untuk mengukur kualitas pelayanan SI perbankan. Kuesioner dibuat menggunakan Skala Likert, dimana kuesioner tersebut akan di isi oleh 30 nasabah. Setelah ditemukan 
nilai rata-rata dari kuesioner, selanjutnya pencarian nilai rata-rata dan maturity level tiap domain, maka akan diperoleh tingkat kualitas pelayanan masing-masing domain[1]. Audit Sistem Informasi Framework Cobit 5, domain DSS digunakan untuk megukur tingkat kematangan implementasi dan integrasi teknologi informasi pada PT. AF dengan target yang sudah ditentukan. Kemudian, setelah target capability level dan capability level ditemukan maka selanjutnya menghitung GAP atau kesenjangan antara target level perusahaan dan capability level yang sudah dicapai oleh perusahaan[5].

\section{METODOLOGI PENELITIAN}

\subsection{Tahapan Penelitian}

Beberapa tahapan untuk mengetahui tingkat kapabilitas pada tata Kelola layanan dan masalah pada PT Telkom Sampit dengan menggunakan kerangka kerja COBIT 5, berikut adalah tahapan/prosesnya:

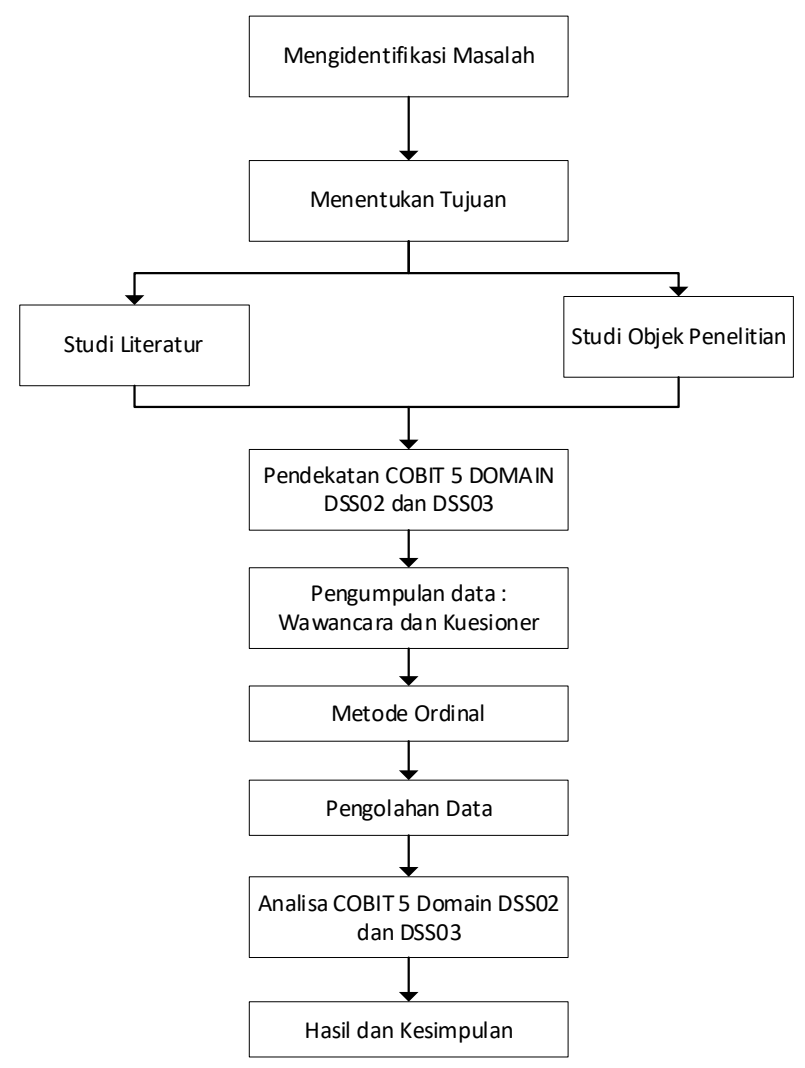

Gambar 1. Tahapan Penelitian

Berikut adalah penjelasan proses atau tahapan yang dilakukan saat penelitian :

a. Identifikasi Masalah dan menentukan tujuan

Pada bagian ini penulisan mengidentifikasi masalah dan menentukan tujuan penelitian, serta melakukan studi pendahuluan yaitu studi Pustaka dan studi objek penlitian.

1. Identifikasi Masalah

Dalam mempermudah menentukan tujuan penelitian, penulis mengidentifikasi masalah terlebih dahulu untuk mengetahui fenomena apa yang terjadi pada objek yang akan dilakukan penelitian.

2. Studi Pustaka

Melakukan perbandingan serta mempelajari metode, objek penelitian, dengan membaca referensi, seperti jurnal, artikel, dan website yang berkaitan dengan objek yang akan diteliti.

3. Studi objek penlitian

Studi objek dilakukan dengan menyiapkan kebutuhan-kebutuhan yang diperlukan untuk audit dari pihak pimpinan IndiHome, kemudian pihak-pihak yang menggunakan jasa pelayan dari IndiHome sebagai responden kuesioner dan wawancara.

b. Metode Pengumpulan Data

1. Wawancara

Mengumpulkan data dengan melakukan tanya jawab secara langung dengan pimpina PT Telkom Sampit yang berkaitan dengan objek penelitian. Serta meminta ijin kepada pihak PT. Telkom Sampit untuk melakukan kuesioner kepada pelanggan mereka.

2. Kuesioner 
Teknik pengumpulan data yang dilakukan dengan cara memberikan sebuah pernyataan dan pertanyaan tertulis kepada responden untuk dijawab[3][6]. Pada penelitian ini responden yang dimiliki berjumlah 12 responden dan diminta untuk menjawab sebuah kuesioner dalam bentuk google form yang berjumlah 10 pertanyaan yang sudah dibuat dan disesuaikan dengan fokus domain yang dipilih DSS02 (Mengelola Layanan Permintaan) 6 pertanyaan, untuk DSS03 (Mengelola Masalah) 4 Pertanyaan, dan akan di isi oleh pengguna/pelanggan produk layanan dari PT Telkom Sampit.

c. Metode Ordinal

Pada penelitian ini penulis melakukan pengolahan data dengan menggunakan Teknik pengukuran ordinal dalam pembuatan kuesioner. Pengukuran ordinal merupakan tingkatan angka yang diberikan dalam pembuatan skala likert. Dengan ukuran nominal digunakan untuk mengurutkan objek dari terendah hinggga tertinggi. Pengurutan objek (nilai rangking) nomor 1 = Sangat Tidak Setuju, $2=$ Tidak Setuju, 3 = Ragu-ragu, $4=$ Setuju, 5 = Sangat Setuju[4].

d. Pengolahan Data

Pada bagian ini data hasil kuesioner akan dilakukan perhitungan dengan menggunakan rumus indeks, nilai rangking dengan nilai absolut (Model Maturity)dilakukan dengan cara melakukan perhitungan dalam bentuk tahapan dengan rumus indeks dibawah ini.

$$
\text { Indeks ke } 1=\frac{\text { Total semua nilai responden }}{\text { Jumlah Responden }}
$$

Setelah perhitungan indeks 1 selesai dengan hasil dari total nilai responden dibagi dengan jumlah responden, lalu dilanjutkan dengan perhitungan rumus indeks kedua seperti berikut :

$$
\text { Indeks ke } 2=\frac{\text { Nilai indeks } 1}{\text { Jumlah Pertanyaan Kuesioner Untuk Setiap Domain }}
$$

Selanjutnya melakukan perhitungan indeks 3 dari hasil perhitungan indeks 2 dengan Nilai indeks 1 dibagi dengan jumlah pertanyaan kuesioner untuk setiap domain, dari hasil tersebut dilakukan perhitungan dengan menggunakan rumus indeks ke 3 berikut

$$
\text { Indeks ke } 3=\frac{\text { Nilai indeks } 2}{\text { Skala ratingnya ada } 5(1 \text { sampai } 5 \text { pilihan })} \times 100 \%
$$

Setelah proses perhitungan dilakukan, dari hasil tersebut dilakukan pengukuran standar tingkat kematangan yang dijadikan sebagai acuan Model Maturity berdasarkan ISACA 2013, seperti pada table berikut :

Tabel 1. Tingkat Maturity Level (ISACA, 2013)

\begin{tabular}{cl}
\hline Index & \multicolumn{1}{c}{ Tingat Maturity Model } \\
\hline 0 & Incomplete Process (Proses Tidak Lengkap) \\
1 & Performed Process (Proses Dijalankan) \\
2 & Managed Process (Proses Diatur) \\
3 & Established Process (Proses Tetap) \\
4 & Predictable Process (Proses Diukur) \\
5 & Optimising Process (Proses Optimasi) \\
\hline
\end{tabular}

Selanjutnya apabila hasil dari perhitungan dari kuesioner telah dijumlahkan dan menghasilkan nilai dalam bentuk bilangan bulat, maka dilakukan skala pembulatan seperti pada tabel berikut ini.

Tabel 2. Skala Pembulatan Indeks

\begin{tabular}{cc}
\hline SKALA & TINGKAT CAPITABILITY MODEL \\
PEMBULATAN & 5 \\
$4,51-5,0$ & 4 \\
$3,51-4,5$ & 3 \\
$2,51-3,5$ & 2 \\
$1,51-2,5$ & 1 \\
$0,51-1,5$ & 0 \\
$0-0,5$ & 0 \\
\hline
\end{tabular}

Tahap selanjutnya adalah analisis GAP, setelah skala pembulatan indeks maka langkah selanjutnya adalah menemukan nilai GAP dengan rumus perhitungan berikut :

$$
\text { GAP = Expected Level Capability - Level Capability }
$$

Expected level diperoleh dari kuesioner, dengan memperkirakan level capability berdasarkan dari nilai jawaban kuesioner yang dipilih terbanyak.

e. Analisa COBIT 5

Pada tahap ini dilakukan pengukuran level dari tiap domain DSS yang diteliti. Pengukuran ini diperoleh berdasarkan pengolahan data hasil kuesioner yang telah diberikan kepada pihak terkait. Hasil dan Kesimpulan.

\subsection{COBIT 5}

COBIT 5 merupakan pengembangan dari COBIT 4.1 yang merupakan salah satu framework yang digunakan untuk melakukan proses audit. COBIT merupakan standar yang dinilai lengkap dengan cakupan yang menyeluruh sebagai 
framework audit. Maka dari itu COBIT dinilai dapat digunakan di berbagai jenis organisasi[7][8]. COBIT 5 memungkinkan untuk mempermudah pada tekonlogi informasi dalam melakukan tata kelola dan manajemen secara holistik untuk keseluruhan enterprise, bertanggung jawab pada keseluruhan area fungsi teknologi informasi. Selain itu juga dalam COBIT 5 menyediakan fasilitas dalam cakupan stakeholder internal dan eksternal. COBIT 5 bersikap global dan bermanfat untuk semua enterprise dengan berbagai skala, baik komersial, non profit, maupun sektor publik [5]. COBIT 5 mempunyai lima prinsip:

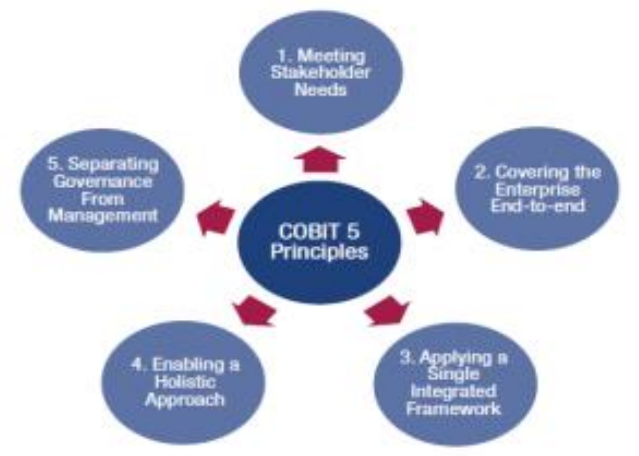

Gambar 2. Prinsip COBIT 5 (ISACA, 2012)

COBIT 5 berdasarkan lima prinsip kunci pada gambar 2.1 untuk tata kelola dan manajemen TI (ISACA, 2012) adalah :

1. Prinsip-1 : Menemukan kebutuhan stakeholder

2. Prinsip-2 : Mencakup ujung ke ujung enterprise

3. Prinsip-3 : Mengaplikasikan yang tunggal, mengintegrasikan framework

4. Prinsip-4 : Mengaktifkan pendekatan holistik

5. Prinsip-5 : Memisahkan tata kelola dengan manajemen

\subsection{Domain DSS}

Delivery, Service Dan Support atau sering disingkat DSS adalah salah satu domain pada COBIT 5. Domain DSS menitikberatkan pada proses pelayanan TI dan dukungan teknisnya yang meliputi hal keamanan sistem, kesinambungan layanan, pelatihan, dan pengelolaan data yang sedang berjalan[4]. Pada penelitian berfokus pada sub domain DSS yaitu DSS02 (Pengelolaan Layanan Dan Insiden) dan DSS03 (Mengelola Masalah). Domain DSS terdiri dari 6 sub domain, sebagai berikut:

1. DSS01 : Mengelola Operasi.

2. DSS02 : Mengelola Permintaan Layanan dan Insiden.

3. DSS03 : Mengelola Masalah.

4. DSS04 : Mengelola Keberlanjutan.

5. DSS05 : Mengelola Keamanan Layanan.

6. DSS06 : Mengelola Kontrol Proses Bisnis.

\section{HASIL DAN PEMBAHASAN}

\subsection{Perhitungan Tingkat Kapabilitas Domain DSS02}

Dari hasil perhitungan diperoleh nilai capability level sub domain DSS02 (Mengelola Permintaan Layanan) pada table berikut:

Tabel 3. Rekapitulasi Capability Level DSS02

\begin{tabular}{|c|c|c|}
\hline No & Sub Domain & Capability Level (Indeks 1) \\
\hline 1 & DSS02.01 & 3,91 \\
\hline 2 & DSS02.02 & 4,25 \\
\hline 3 & DSS02.03 & 4,08 \\
\hline 4 & DSS02.04 & 4,08 \\
\hline 5 & DSS02.05 & 3,91 \\
\hline \multirow[t]{4}{*}{6} & DSS02.06 & 3,83 \\
\hline & Jumlah Indeks 1 & 24,08 \\
\hline & Indeks 2 (Current Capability) & 4,01 \\
\hline & Indeks 3 (Level Capability 100\%) & 80,27 \\
\hline
\end{tabular}

\subsection{Perhitungan Tingkat Kapabilitas Domain DSS03}

Dari hasil perhitungan diperoleh nilai capability level sub domain DSS03 (Mengelola Masalah) pada table berikut : 
Tabel 4. Rekapitulasi Capability level DSS03

\begin{tabular}{|c|c|c|}
\hline No & Sub Domain & Capability Level (Indeks 1) \\
\hline 1 & DSS03.01 & 3,66 \\
\hline 2 & DSS03.02 & 4 \\
\hline 3 & DSS03.03 & 4 \\
\hline 4 & DSS03.04 & 4,08 \\
\hline & Jumlah Indeks 1 & 15,75 \\
\hline & Indeks 2 (Current Capability) & 3,93 \\
\hline & Indeks 3 (Level Capability 100\%) & 78,75 \\
\hline
\end{tabular}

\subsection{Level Kapabilitas}

Berikut adalah capability level domain DSS02 dan DSS03 diperoleh dari hasil perhitungan pada Tabel 3 dan Tabel 4, terdapat dua bagian yaitu current capability dan dalam bentuk persentase.

Tabel 5. Capability Level

\begin{tabular}{ccc}
\hline Domain & Current Capability & Persentase (\%) \\
\hline DSS02 & 4,01 & 80,28 \\
DSS03 & 3,94 & 78,75 \\
\hline
\end{tabular}

\subsection{Pembulatan Indeks Dan Analisis GAP}

Berikut adalah Analisa GAP dan Pembulatan indeks berdasarkan skala pembulatan indeks (ISACA, 2013).

Tabel 6. Pembulatan Skala Indeks Dan Analisis GAP

\begin{tabular}{ccc|c|c}
\hline Domain & Current Capability & Capability Level & Expected Level & GAP \\
\hline DSS02 & 4,01 & 4 & 5 & 1 \\
DSS03 & 3,94 & 4 & 5 & 1 \\
\hline
\end{tabular}

Pada Tabel 6. diperoleh hasil capability level DSS02 (Mengelola Permintaan Layanan) berada pada level 4 Predictable Process (Proses Diukur) dan DSS03 (Mengelola Masalah) Predictable Process (Proses Diukur)

\section{KESIMPULAN}

Berdasarkan hasi perhitungan diperoleh capability level PT Telkom Sampit yaitu DSS02 (Mengelola Permintaan Layanan) berada pada level 4 Predictable Process (Proses Diukur), dan DSS03 (Mengelola Masalah) Predictable Process (Proses Diukur) berada pada level 4 Predictable Process (Proses Diukur). Walaupun tidak sesuai dengan expected level yang harusnya di level 5 , tetapi berada pada level 4 ini termasuk kedalam level yang bagus untuk sebuah perusahaan.

\section{REFERENCES}

[1] I. Elyana, "Analisis Pengukuran Kualitas Pelayanan Sistem Informasi Perbankan Dengan Menggunakan Cobit 5", J-SAKTI (Jurnal Sains Komput. dan Inform., vol 1, no 2, bl 237, 2017, doi: 10.30645/j-sakti.v1i2.47.

[2] G. I. Belo, Y. T. Wiranti, en L. H. Atrinawati, "Perancangan Tata Kelola Teknologi Informasi Menggunakan Cobit 2019 Pada PT Telekomunikasi Indonesia Regional VI Kalimantan”, JUSIKOM PRIMA (Jurnal Sist. Inf. Ilmu Komput. Prima), vol 4, no 1, bll 23-30, 2020.

[3] C. B. Santoso en A. A. Saleh, "Penerapan Metode Cobit 5.0 Domain Dss02 Dan Dss03 Untuk Mengukur Tingkat Kapabilitas Tata Kelola Sistem Di PT. Indofood Cbp Sukses Makmur Tbk.”, Teknois J. Ilm. Teknol. Inf. dan Sains, vol 7, no 2, bll 13-26, 2019, doi: 10.36350/jbs.v7i2.24.

[4] T. S. Agoan, H. F. Wowor, en S. Karouw, "Analisa Tingkat Kematangan Teknologi Informasi Pada Dinas Komunikasi Dan Informatika Kota Manado Menggunakan Framework COBIT 5 Domain Evaluate, Deirect, Monitor (EDM) dan Deliver, Service, and Support (DSS)", J. Tek. Inform., vol 10, no 1, bll 1-9, 2017, doi: 10.35793/jti.10.1.2017.15627.

[5] M. A. Ali, "Audit Sistem Informasi Framework Cobit 5", vol 7, no 2, bll 37-42, 2020, doi: 10.31219/osf.io/yp5u2.

[6] L. D. Oktaviana, P. Pribadi, en M. Sabrinawati, "Evaluasi IT Governance Menggunakan Framework COBIT 5 ( Studi Kasus : PT . XYZ )", Pro Bisnis, vol 12, no 1, bll 56-68, 2019.

[7] A. Nuratmojo, E. Darwiyanto, S. T. Mt, G. Agung, A. Wisudiawan, en S. Kom, "Penerapan COBIT 5 Domain DSS ( Deliver , Service, Support ) untuk Audit Infrastruktur Teknologi Informasi FMS PT Grand Indonesia Application COBIT 5 DSS (Deliver , Service, and Support ) Domain for Information Technology Infrastructure Audit FMS PT Gra", e-Proceeding Eng., vol 2, no 2, bll 6499-6506, 2015

[8] A. Nuraeni, "Dengan Menambahkan Unsur Keamanan Menggunakan Framework Cobit 5 Pada Domain Dss", J. Comput. Bisnis, vol 10, no 2, bll 89-105, 2016. 